\title{
Monitoring West Nile virus (WNV) infection in wild birds in Serbia during 2012: first isolation and characterisation of WNV strains from Serbia
}

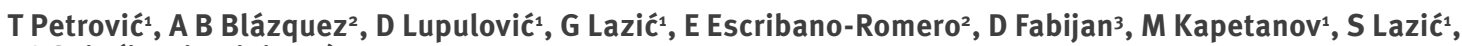

J C Saiz (jcsaiz@inia.es)

1. Scientific Veterinary Institute "Novi Sad", Novi Sad, Serbia

2. Department of Biotechnology, Instituto Nacional de Investigación y Tecnología Agraria y Alimentaria (INIA), Madrid, Spain

3. Bird Protection and Study Society of Serbia, Novi Sad, Serbia

Citation style for this article:

Petrović T, Blázquez AB, Lupulović D, Lazić G, Escribano-Romero E, Fabijan D, Kapetanov M, Lazić S, Saiz JC. Monitoring West Nile virus (WNV) infection in wild birds in Serbia during 2012: first isolation and characterisation of WNV strains from Serbia. Euro Surveill. 2013;18(44):pii=20622. Available online: http://www. eurosurveillance.org/ViewArticle.aspx?Articleld=20622

Article submitted on 02 January 2013/ published on 31 October 2013

West Nile virus (WNV), a neurovirulent mosquitotransmissible zoonotic virus, has caused recent outbreaks in Europe, including Serbia from August until October 2012. Although humans can be infected, birds are the main natural WNV reservoir. To assess WNV circulation in northern Serbia, 133 wild birds were investigated. These comprised resident and migratory birds, collected between January and September 2012 in the Vojvodina province. The birds belonged to 45 species within 27 families. Blood sera $(n=92)$ and pooled tissues from respective birds $(n=81)$ were tested by enzyme-linked immunosorbent assay (ELISA), plaque reduction neutralisation test (PRNT) and real-time reverse transcription-polymerase chain reaction (RT-qPCR). WNV antibodies were detected in seven ( $8 \%$ ) sera: four from Mute Swans (Cygnus olor), two from White-tailed Eagles (Haliaeetus albicillas), and one from a Common Pheasant (Phasianus colchicus). Five sera neutralised WNV but not Usutu virus. For the first time in Serbia, WNV RNA was detected by RT-qPCR in pooled tissue samples of eight respective birds. WNV RNA was also derived from an additional bird, after a serum sample resulted infective in cell culture. The total nine WNV RNA positive birds included three Northern Goshawks (Accipiter gentilis), two White-tailed Eagles, one Legged Gull (Larus michahelis), one Hooded Crow (Corvus cornix), one Bearded Parrot-bill (Panarus biramicus), and one Common Pheasant. Phylogenetic analysis of partial $E$ region sequences showed the presence of, at least, two lineage 2 Serbian clusters closely related to those responsible for recent human and animal outbreaks in Greece, Hungary and Italy. Full genomic sequence from a goshawk isolate corroborated this data. These results confirm WNV circulation in Serbia and highlight the risk of infection for humans and horses, pointing to the need for implementing WNV surveillance programmes.

\section{Introduction}

West Nile virus (WNV) a neurovirulent mosquito-transmissible Flavivirus is maintained in nature in an enzootic transmission cycle between birds and mosquitoes. Although WNV infections have been described in a wide variety of vertebrates, birds are the main natural reservoir. Hundreds of wild and domestic avian species have been described as susceptible to WNV infection, but many of these showed only subclinical infection [1]. In Europe, the reported seroprevalence in birds has been generally low, 1 to $10 \%$, being usually higher among migratory than resident birds [2-8]. This leads to suggest that migratory birds may play a pivotal role in spreading WNV infection. Nevertheless, some studies pointed to resident birds as important in maintaining WNV circulation in nature $[9,10]$.

Aside from birds, humans and horses are occasionally infected by WNV and sporadic disease outbreaks can occur that may result in fatalities [11]. In Europe WNV has been sporadically detected for decades but, since the 1990s, the number and frequency of outbreaks associated with severe disease including neurological manifestation have increased dramatically, and the virus is spreading throughout the Mediterranean basin and some European surrounding countries, constituting a serious veterinary and public health problem [11].

The genome of WNV is a single stranded RNA molecule of positive polarity with about 11,000 nucleotides that render three structural and seven non-structural proteins [11]. Of five WNV lineages, lineage 1 and 2 are the most widespread in the world [11]. Until 2004, only lineage 1 strains were circulating in Europe, but in 2004, a lineage 2 strain was isolated for the first time in Hungary from a goshawk [12]. Since, lineage 2 strains in several wild birds, mosquitoes, sentinel chickens, and humans have been consecutively isolated in Hungary, Austria, Italy, and also in Greece [12-17], where WNV 
accounted for more than 250 human clinical cases and more than 30 deaths.

Few data are available on WNV activity in Serbia. Early reports during the 1970 s described the prevalence of anti-WNV antibodies in human populations of the former Yugoslavia that ranged from $1 \%$ to $8 \%$ depending of the studied region of the country [18-20]. Recently, anti-WNV IgG were detected in $4 \%(18 / 451)$ of human sera collected from 2005 to 2010 in the Vojvodina province, the place of sampling of the present report, and WNV RNA was detected in six of 841 mosquito pools, mainly from 2010 [21]. Twelve per cent of the horses investigated during 2009 and 2010 in the same province tested seropositive [22]. From August to October 2012, an outbreak of WNV clinical infection in humans was reported for the first time ever in the central and northern part of Serbia, including the Vojvodina province [23]. Of 58 reported cases, 45 were confirmed and 13 were probable. Nine were fatal. In light of all previously conducted studies, the objective of the present study was the serological and molecular assessment of WNV activity in wild resident and migratory birds, as virus natural hosts, in the Vojvodina province. The surveillance period which extended from January to September 2012 covered a time before and during the first human WNV outbreak in Serbia.

\section{Methods}

\section{Samples}

Samples $(n=133)$ from living-captured wild birds, wild birds that died in a rehabilitation centre, or from birds found dead were collected between January and September 2012 in the Serbian province of Vojvodina. Birds collected in the context of bird-ringing activities were captured by traps and mist nets, bled, ringed, and released. From dead birds, blood exudates were collected from heart or from pleural or abdominal cavity. A pool of selected tissues (brain, kidney, liver, lung and spleen) was created from each dead bird. In total 92 blood serum samples from 30 wild bird species were examined for the presence of anti-WNV antibodies. Additionally, 81 pools of tissue samples from birds belonging to 35 species were homogenised as described $[24,25]$ and examined for the presence WNV RNA. Detection of infective virus was assayed on Vero cell culture by standard procedures [26].

\section{Enzyme-linked immunosorbent assay (ELISA)} Anti-WNV IgG was detected by a validated ELISA based on WNV recombinant envelope $E(\mathrm{rE})$ protein [27]. The positive cut-off value was assigned using a positive/ negative $(P / N)$ ratio of $\geq 2$.

\section{Plaque reduction neutralisation test (PRNT)}

Neutralising antibodies were detected by PRNT on Vero cells [28] using a fixed amount (100 plaque-forming unit (PFU)) of cultured passage WNV-NY99 strain $[24,26]$ and two-fold dilutions of serum (starting from 1:20). Neutralising antibody titration was established as the highest serum dilution that inhibits plaque formation by $90 \%\left(\mathrm{PRNT}_{90}\right)$. In those samples in which enough serum volume was available, and as control of flaviviral specific reactivity, PRNT was similarly performed with Usutu virus (USUV) strain SAAR 1776, the only other flavivirus of the Japanese encephalitis serocomplex circulating in Europe [29].

\section{Detection of West Nile virus RNA}

RNA was extracted from each of 81 homogenised tissues/organs pools $[25,27]$, or from sera that resulted infective in cell culture, using a commercial kit (Speedtools RNA virus extraction kit, Biotools B and M Labs S.A, Madrid, Spain) following manufacturer's instruction. RNA extracts were amplified by realtime reverse transcription-polymerase chain reaction (RT-qPCR) using primers and probes that target the capsid and 5 untranslated genomic regions of both WNV lineage 1 and 2 [2]. Positive samples were further tested employing a primer pair (forward: 5'CCAAACAATCTGTTGTGGCTCTAG-3' and reverse: 5'-(AGCGAATTTAAACGCTTTTGAAC-3'), designed for the specific detection of WNV lineage 2 and targeting a 194 bp fragment of the $E$ genomic region (nucleotides: 1,709 to 1,903 according to Uganda B956 lineage 2 strain, GenBank accession number: AY532665), and SuperScript One-Step RT-PCR with Platinum Taq (Molecular Probes, Eugene, 0), as described [26].

\section{Sequencing and phylogenetic analysis}

A fragment targeting the first 1,903 nucleotides of WNV-RNA positive samples was amplified by reverse transcription of viral RNA as above using primers 5'-CAGCGAATTTAAACGCTTTTGAAC-3'and 5'AGTAGTTCGCCTGTGTGAGC -3', and bi-directionally sequenced (Macrogen Inc. Seoul, Korea). In addition, the complete viral genome sequence of a positive goshawk, here termed SRB-Novi Sad/12 (GenBank

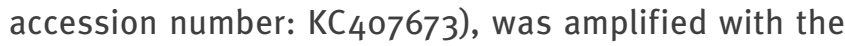
appropriate oligonucleotide primers (available upon request), purified, and sequenced.

Nucleotide sequence comparisons and phylogenetic analysis were conducted with the Serbian sequences and representative strains of lineage 1 and 2 retrieved from GenBank. Trees were built by the neighbour-joining method from a multiple alignment using ClustalW and Phylogeny.fr [30] after 100 replications for bootstrapping and visualised with TreeView.

\section{Results}

Of 92 wild bird sera tested, seven (8\%) were IgG ELISA positive (Table). They belonged to three species: four Mute Swans (species: Cygnus olor; order: Anseriformes); two White-tailed Eagles (Haliaeetus albicilla; Accipitriformes); and one Common Pheasant (Phasianus colchicus; Galliformes). Of the seven ELISA positive samples, five samples neutralised WNV in cell culture with relatively low $\mathrm{PRNT}_{90}$ values while one sample from a swan and one from an eagle did not neutralise WNV (Table). Only the White-tailed Eagle serum 
West Nile virus surveillance results on wild migratory and resident birds sampled in the province of Vojvodina, northern Serbia, January-September 2012

\begin{tabular}{|c|c|c|c|c|c|c|}
\hline Order & Family & $\begin{array}{c}\text { Resident/ } \\
\text { Migratory } \\
\text { status }\end{array}$ & Species & $\begin{array}{l}\text { WNV } \\
\text { ELISA }^{a}\end{array}$ & $\begin{array}{l}\text { WNV } \\
\text { PRNT }^{\mathrm{b}}\end{array}$ & $\begin{array}{c}\text { WNV } \\
\text { RT-qPCR }\end{array}$ \\
\hline Anseriformes & Anatidae & $\mathrm{r} / \mathrm{m}$ & Cygnus olor - Mute Swan & $4 / 17$ & $3 / 17$ & NA \\
\hline Gruiformes & Rallidae & $\mathrm{r} / \mathrm{m}$ & Rallus aquaticus - Water Rail & NA & NA & $0 / 1$ \\
\hline \multirow{3}{*}{ Charadriformes } & \multirow{3}{*}{ Laridae } & $\mathrm{r} / \mathrm{m}$ & Chroicocephalus ridibundus - Black-headed Gull & $0 / 5$ & $0 / 5$ & $0 / 6$ \\
\hline & & $\mathrm{r} / \mathrm{m}$ & Larus michahellis - Yellow-legged Gull & NA & NA & $1 / 1$ \\
\hline & & $\mathrm{r} / \mathrm{m}$ & Ichthyaetus melanocephalus - Mediterranean Gull & NA & NA & $0 / 2$ \\
\hline \multirow{2}{*}{ Galliformes } & \multirow{2}{*}{ Phasianidae } & $r$ & Alectoris graeca - Rock Patridge & NA & NA & $0 / 1$ \\
\hline & & $\mathrm{r}$ & Phasianus colchicus - Common Pheasant & $1 / 1$ & $1 / 1$ & $1 / 1$ \\
\hline Podicipediformes & Podicipedidae & $\mathrm{r} / \mathrm{m}$ & Podiceps cristatus - Great Crested Grebe & $0 / 1$ & $0 / 1$ & $0 / 1$ \\
\hline \multirow{2}{*}{ Pelecaniformes } & \multirow{2}{*}{ Ardeidae } & $\mathrm{r} / \mathrm{m}$ & Ardea cinerea - Grey Heron & $0 / 1$ & $0 / 1$ & $0 / 1$ \\
\hline & & $\mathrm{m}$ & Ixobrychus minutus - Little Bittern & $0 / 1$ & $0 / 1$ & $0 / 3$ \\
\hline Ciconiiformes & Ciconiidae & $\mathrm{m}$ & Ciconia ciconia - White Stork & $0 / 2$ & $0 / 2$ & $0 / 3$ \\
\hline \multirow{7}{*}{ Accipitriformes } & Pandionidae & $\mathrm{m}$ & Pandion haliaetus - Osprey & $0 / 1$ & $0 / 1$ & $0 / 1$ \\
\hline & Falconidae & $\mathrm{r} / \mathrm{m}$ & Falco tinnunculus - Common Kestrel & $0 / 2$ & $0 / 2$ & $0 / 4$ \\
\hline & \multirow{5}{*}{ Accipitridae } & $\mathrm{r} / \mathrm{m}$ & Circus aeruginosus - Western Marsh Harrier & NA & NA & $0 / 1$ \\
\hline & & $\mathrm{m}$ & Buteo buteo - Common Buzzard & $0 / 4$ & $0 / 4$ & $0 / 8$ \\
\hline & & $r$ & Accipiter gentilis - Northern Goshawk & $0 / 3$ & $0 / 3$ & $3 / 3$ \\
\hline & & $r$ & Accipiter nisus - Eurasian Sparrowhawk & NA & NA & $0 / 2$ \\
\hline & & $r$ & Haliaeetus albicilla - White-tailed Eagle & $2 / 6$ & $1^{d} / 6$ & $1 / 8$ \\
\hline \multirow{3}{*}{ Strigiformes } & \multirow{3}{*}{ Strigidae } & $r$ & Athene noctua - Little Owl & NA & NA & $0 / 1$ \\
\hline & & $\mathrm{r}$ & Tyto alba - Barn Owl & $0 / 1$ & $0 / 1$ & $0 / 3$ \\
\hline & & $\mathrm{m}$ & Asio otus - Long-eared Owl & $0 / 4$ & $0 / 4$ & $0 / 6$ \\
\hline Apodiformes & Apodidae & $\mathrm{m}$ & Apus apus - Common Swift & NA & NA & $0 / 1$ \\
\hline Cuculiformes & Cuculidae & $m$ & Cuculus canorus - Common Cuckoo & NA & NA & $0 / 1$ \\
\hline \multirow{2}{*}{ Coraciiformes } & Meropidae & $\mathrm{m}$ & Merops apiaster - European Bee-eater & $0 / 1$ & $0 / 1$ & $0 / 1$ \\
\hline & Coraciidae & $\mathrm{m}$ & Coracias garrulus - European Roller & $0 / 2$ & $0 / 2$ & NA \\
\hline \multirow{2}{*}{ Columbiformes } & \multirow{2}{*}{ Columbidae } & $\mathrm{r}$ & Columba Livia domestica - Domestic Pigeon & $0 / 1$ & $0 / 1$ & NA \\
\hline & & $\mathrm{r}$ & Streptopelia decaocto - Eurasian Collared-dove & $0 / 1$ & $0 / 1$ & $0 / 1$ \\
\hline \multirow{19}{*}{ Passeriformes } & Hirundinidae & $\mathrm{m}$ & Hirundo rustica - Barn Swallow & $0 / 1$ & $0 / 1$ & $0 / 1$ \\
\hline & Muscicapidae & $\mathrm{r} / \mathrm{m}$ & Erithacus rubecula - European Robin & NA & NA & $0 / 1$ \\
\hline & Turdidae & $\mathrm{r} / \mathrm{m}$ & Turdus merula - Eurasian Blackbird & $0 / 2$ & $0 / 2$ & $0 / 3$ \\
\hline & \multirow{3}{*}{ Acrocephalidae } & $\mathrm{m}$ & Acrocephalus schoenobaenus - Sedge Warbler & $0 / 4$ & $0 / 4$ & NA \\
\hline & & $\mathrm{m}$ & Acrocephalus scirpaceus - Eurasian Reed-warbler & $0 / 4$ & $0 / 4$ & NA \\
\hline & & $\mathrm{m}$ & Acrocephalus arundinaceus - Great Reed-warbler & $0 / 12$ & $0 / 12$ & NA \\
\hline & Sylviidae & $\mathrm{m}$ & Sylvia atricapilla - Blackcap & $0 / 2$ & $0 / 2$ & NA \\
\hline & Phylloscopidae & $\mathrm{m}$ & Phylloscopus sibilatrix - Wood Warbler & NA & NA & $0 / 1$ \\
\hline & \multirow{2}{*}{ Corvidae } & $\mathrm{r}$ & Pica pica - Black-billed Magpie & $0 / 1$ & $0 / 1$ & $0 / 2$ \\
\hline & & $\mathrm{r}$ & Corvus cornix - Hooded Crow & $0 / 1$ & $0 / 1$ & $1 / 1$ \\
\hline & \multirow{2}{*}{ Passeridae } & $\mathrm{r} / \mathrm{m}$ & Passer montanus - Eurasian Tree Sparrow & $0 / 4$ & $0 / 4$ & NA \\
\hline & & $\mathrm{r} / \mathrm{m}$ & Passer domesticu - House Sparrow & $0 / 3$ & $0 / 3$ & NA \\
\hline & \multirow{4}{*}{ Fringillidae } & $\mathrm{r} / \mathrm{m}$ & Carduelis cannabina - Eurasian Linnet & NA & NA & $0 / 2$ \\
\hline & & $\mathrm{r} / \mathrm{m}$ & Carduelis carduelis - European Goldfinch & NA & NA & $0 / 6$ \\
\hline & & $\mathrm{r} / \mathrm{m}$ & Carduelis spinus - Eurasian Siskin & NA & NA & $0 / 1$ \\
\hline & & $\mathrm{r} / \mathrm{m}$ & Chloris chloris - European Greenfinch & NA & NA & $0 / 1$ \\
\hline & Emberizidae & $\mathrm{r} / \mathrm{m}$ & Emberiza schoeniclus - Reed Bunting & $0 / 2$ & $0 / 2$ & NA \\
\hline & Timaliidae & $\mathrm{r}$ & Panurus biarmicus - Bearded Parrotbill & $0 / 1$ & $0 / 1$ & $1 / 1$ \\
\hline & Total(27) & & 45 species & $7 / 92(8 \%)$ & $5 / 92(5 \%)$ & $8 / 81(10 \%)$ \\
\hline
\end{tabular}

ELISA: enzyme-linked immunosorbent assay; m: strictly migratory birds; NA: not applicable; PRNT: plaque reduction neutralisation test; r: strictly resident birds; $r / m$ : resident and migratory birds at the same time, mostly resident but could migrate depending of the weather; RTqPCR: real-time reverse transcription-polymerase chain reaction; WNV: West Nile virus.

a Testing of birds blood sera samples for the presence of anti-WNV IgG antibodies by ELISA (positive/tested). Positive/negative (P/N) values of positive samples: Mute Swans: 2.3, 2.6, 2.3 and 2.7; White-tailed Eagles: 3.9 and 11.2; Common Pheasant: 6.8.

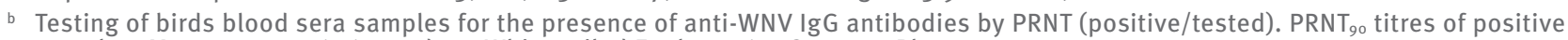
samples: Mute swans: 56, 63, and 30; White-tailed Eagle: > 160; Common Pheasant: 44.

Testing of bird tissue samples pools for the presence of WNV RNA by RT-qPCR (positive/tested). The complete genome from one Northern Goshawk isolate, SRB-Novi Sad/12 (GenBank accession number: KC407673), was sequenced. Isolates: SRB-7193-13/12 (GenBank accession number: KC 407671), SRB-7193-14/12 (GenBank accession number: KC407672), SRB-6989/12 (GenBank accession number: KC407668), SRB7193-10/12 (GenBank accession number: KC407670) and SRB-7193-3/12 (GenBank accession number: KC407669) from a Common Pheasant, a White-tailed Eagle, a Bearded Parrot-bill, a Hooded Crow and another Northern Goshawk, respectively, were partially sequenced (genome fragment of the $E$ region).

d Blood serum sample positive for infectious WNV on Vero E6 cell culture. 


\section{FIGURE 1}

Location of birds sampled for West Nile virus testing in Vojvodina province and test results, northern Serbia, JanuarySeptember 2012

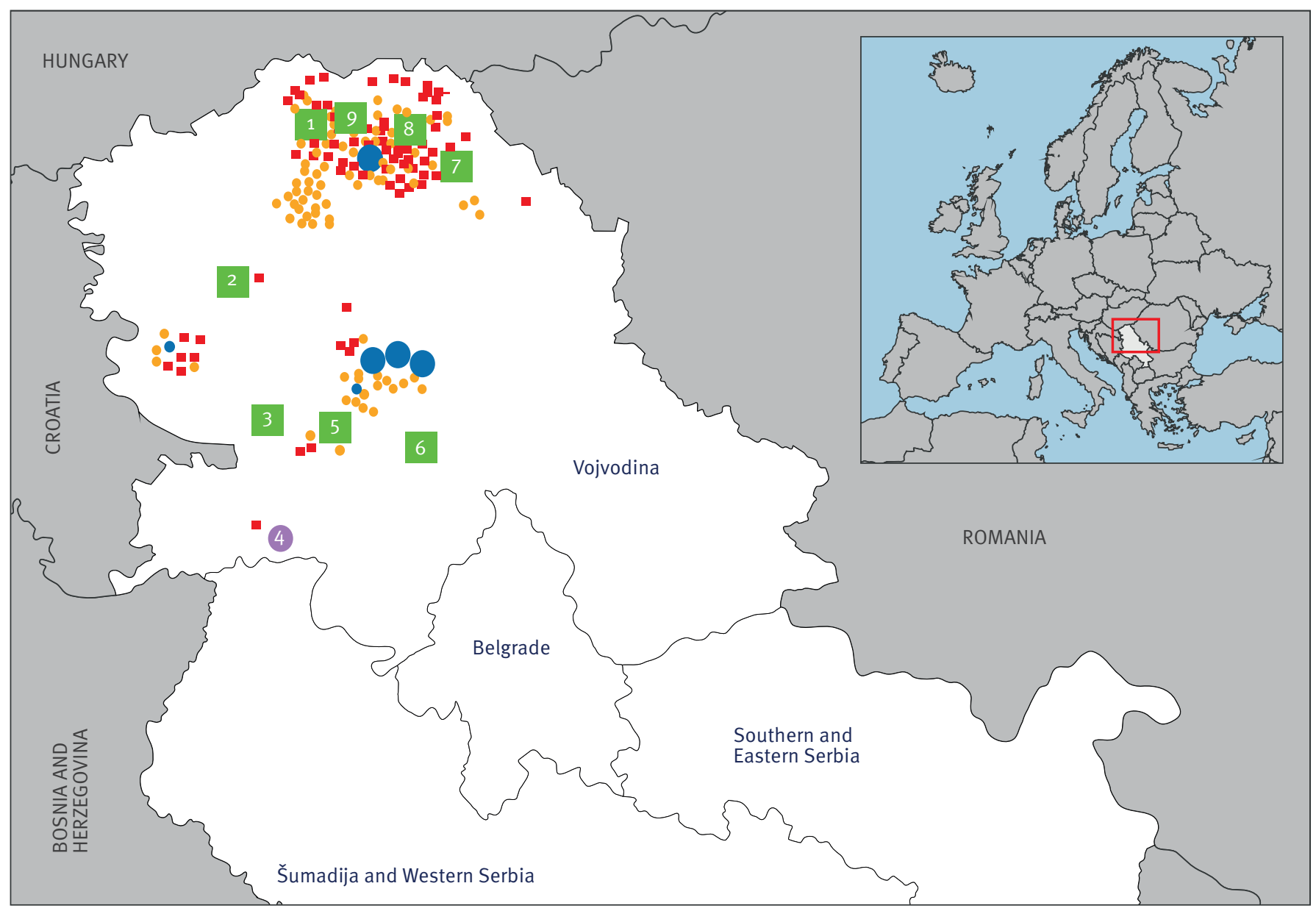

Orange circles: anti-WNV antibodies negative blood sera samples (ELISA and PRNT).

Small red squares: WNV RT-qPCR negative tissue sample pools.

Small blue circles: anti-WNV antibodies positive sera samples (ELISA).

Big blue circles: anti-WNV antibodies positive sera samples (ELISA and PRNT).

Big violet circle: serum sample positive for infectious WNV and for anti-WNV antibodies (ELISA and PRNT).

Big green squares: WNV RT-qPCR positive tissue samples.

ELISA: enzyme-linked immunosorbent assay; PRNT: plaque reduction neutralisation test; RT-qPCR: real-time reverse transcription-polymerase chain reaction; WNV: West Nile virus.

West Nile virus isolates: 1) SRB-7193-13/12 (Common Pheasant, Phasianus colchicus); 2) SRB-7193-14/12 (White-tailed Eagle, Haliaeetus albicilla); 3) SRB-6989/12 (Bearded Parrot-bill, Panarus biramicus); 4) SRB-7193-11/12 (White-tailed Eagle, Haliaeetus albicilla); 5) SRB-Novi $\mathrm{Sad} / 12$ (full genome sequenced isolate from Northern Goshawk, Accipiter gentilis); 6) SRB-7193-10/12 (Hooded Crow, Corvus cornix); 7) SRB-7193-3/12 (Northern Goshawk, Accipiter gentilis); 8) SRB-7193-4/12 (Yellow-legged Gull, Larus michahelis); 9) SRB-7193-7/12 (Northern Goshawk, Accipiter gentilis).

with the highest $\mathrm{P} / \mathrm{N}$ value (11.2) had a $\mathrm{PRNT}_{90}{ }_{1160}$. Of the 12 sera tested by PRNT for USUV ( 6 WNV-ELISA positives and 6 negatives), only one (a WNV-ELISA positive serum) neutralised USUV $\left(\mathrm{PRNT}_{90}=70\right)$, but it did not neutralise WNV.

A total of 81 pools of tissue samples from wild bird carcases belonging to 35 species were examined for the presence of WNV RNA and eight (10\%) tested positive
(Table). These correspond to three Northern Goshawks, one Bearded Parrot-bill, one Common Pheasant, one Legged Gull, one Hooded Crow, and one White-tailed Eagle, all of which died during winter-spring and summer of 2012.

In addition, one serum sample resulted infective in cell culture and was subsequently confirmed to be WNV RNA positive. This sample, which was from a 
Phylogenetic analysis based on complete genome nucleotide sequences of a West Nile virus strain derived from a goshawk in Vojvodina province, Serbia 2012

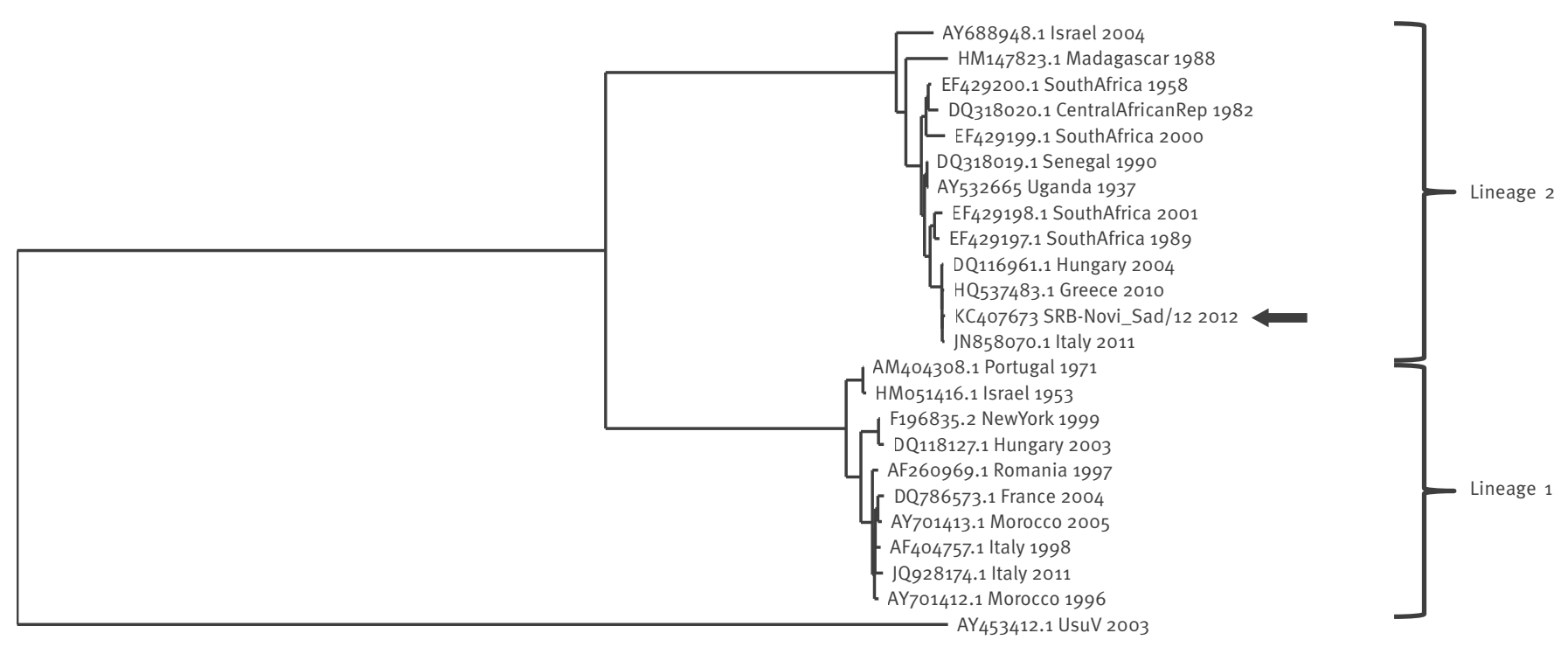

0.5

The SRB-Novi Sad/12 isolate (GenBank accession number: KC407673) from the gowshawk recovered in this study is marked with an arrow. GenBank accession numbers, geographic origin and year of isolation of samples are shown. The scale bar depicts genetic distance. The Usutu virus USUV SAAR1776 strain was used as out-root.

White-tailed Eagle, had shown the highest P/N (11.2) and PRNT $_{90}(>160)$ titres, and was collected in July 2012 (Table).

The complete genome sequence was obtained from an isolate originating from a Northern Goshawk (SRB-Novi $\mathrm{Sad} / 12$ ) that was found dead in the Vojvodina province (the exact location is not known) during the spring of 2012 (Figure 1). Virus from this tissue sample was successfully amplified after a single passage on Vero cells. No anti-WNV antibodies had been detected in the serum.

Pairwise alignment of the SRB-Novi Sad/12 isolate sequence with representative WNV lineage 1 and 2 complete genomes sequences revealed that it belongs to lineage 2 (Figure 2) and clusters with recent WNV strains isolated in Hungary in 2004, Greece in 2010, and Italy in 2012, with which it presents the highest similarities, $99.51 \%$, $99.47 \%$ and $99.45 \%$, respectively. Percentage of similarity with the other lineage 2 sequences analysed varied between 93.03\% (Israel 1999 isolate) and $97.65 \%$ (South African 1989 isolate), whilst homology with lineage 1 New York 1999 isolate was $79.53 \%$. A total of 29 unique nucleotides scattered through the genome were found in the SRB-Novi Sad/12 isolate when compared to those circulating lately in Europe. Only one of these nucleotide substitutions
$\left(\mathrm{T}_{5343 \mathrm{~A}}\right)$ results in an amino acid change in the NS3 region ( $\mathrm{H} 244 \mathrm{Q})$.

Further analysis of partial E sequences (863 nucleotides) from the other Serbian birds, which except for a pheasant collected in winter-early spring, were all collected during the summer of 2012, confirms that these sequences also belong to lineage 2; however, two clusters of sequences were clearly distinguishable (Figure 3), a first cluster with sequences (from a pheasant and an eagle) showing $100 \%$ similarity with SRB-Novi Sad/12 isolate, and a second cluster with sequences, showing four to five synonymous nucleotides variations compared with the SRB-Novi Sad/12 isolate. The latter isolates were from a crow and a parrot-bill (with four synonymous substitutions) as well as a goshawk, (with five synonymous substitutions). The Serbian sequences in the second cluster are highly similar, only one nucleotide variation (two in the case of the goshawk isolate) in the region analysed, with a strain identified from a mosquitoes pool in Greece in 2010 [14].

\section{Discussion}

The presence and circulation of WNV among wild resident and migratory birds in Serbia was serologically confirmed, for the first time, as seven ( $8 \%$ ) of the 92 serum samples investigated, which belong to birds of 30 species within 21 families of 11 different orders, 


\section{FIGURE 3}

Phylogenetic analysis of West Nile virus (WNV) strains detected in Vojvodina province based on partial genome nucleotide sequences from the $\mathrm{E}$ region of the WNV genome, Serbia, 2012

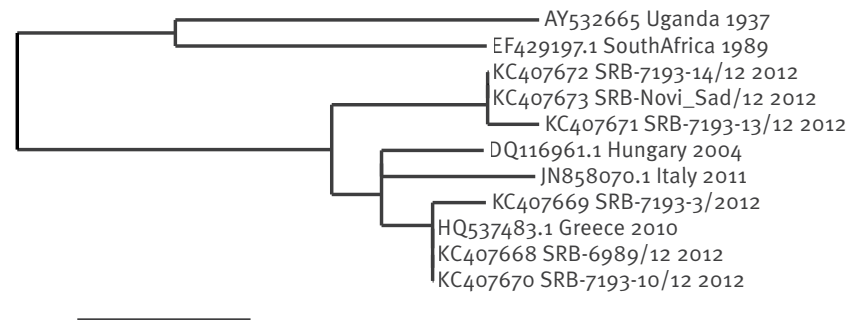

0.004

SRB: Serbian strains.

GenBank accession numbers geographic origin and year of isolation of samples are shown. The scale bar depicts genetic distance. SRB-7193-13/12 (Common Pheasant); SRB-7193-14/12 (White-tailed Eagle); SRB-Novi Sad/12 (Northern Goshawk); SRB 7193-3/12 (Northern Goshawk); SRB-7193-10/12 (Hooded Crow); SRB-6989/12 (Bearded Parrot-bill).

presented anti-WNV IgG. Birds testing positive belong to three orders and three species: four Mute Swans, two White-tailed Eagles, and one Common Pheasant. Five of the seven birds had neutralising antibodies with relatively low titres, except for one White-tailed Eagle which presented a PRNT $_{90}>160$. None of these five sera neutralised USUV. Only one serum sample of a total of 12, which were tested for USUV, neutralised USUV, but this WNV-ELISA positive sample did not neutralise WNV, confirming the circulation of USUV in the region [22]. The prevalence of WNV seropositive birds found in the northern part of Serbia ( $8 \%$ ) is similar to that previously described in other European countries, $1 \%$ to $10 \%$ [2-8], suggesting that, even though WNV entrance in Serbia has probably been a recent event, the virus is currently circulating with the same intensity than in surrounding countries.

Birds have been implicated in spreading WNV infection during their migration [11]. Anti-WNV antibodies are usually less frequently found among resident birds than migratory birds, suggesting that they can act as reservoirs of WNV and carry the virus over long distances, while resident wild birds can act as amplifiers of local WNV strains. Three of the seropositive birds found here were resident birds (two White-tailed Eagles and one Common Pheasant), while the other four (Mute Swans) are considered both migratory and resident birds in Serbia. Samples were collected from winter-early spring to late summer 2012, suggesting that WNV infects both wild resident and migratory birds and point to a possible overwintering and expansion of the virus in the province of Vojvodina. However, as the number of samples tested was limited, a more detailed surveillance analysis should be conducted as part of future investigations to clarify this point.

RNA amplification was achieved in tissue samples from eight birds, which were found dead: one Bearded Parrot-bill, one Common Pheasant, one Hooded Crow, one Legged Gull, three Northern Goshawks, and one White-tailed Eagle. Six of these birds died during the summer of 2012 while two (a pheasant and a goshawk) died during winter-early spring. Serum from another White-tailed Eagle (found dead in August 2012) was infective in cell culture, and subsequently confirmed to be WNV RNA positive. Notably, this infective serum showed the highest $\mathrm{P} / \mathrm{N}$ and $\mathrm{PRNT}_{90}$ titres, thus, pointing to a very recent infection. Eight of the nine WNVRNA positive birds were strictly resident, suggesting that they became infected in the country. Moreover, isolation of WNV-RNA from dead predators ( 5 of the 9 WNV positive birds) provides more evidence that birds of prey play a key role in virus transmission $[12,15,16]$.

Phylogenetic analysis of the complete genomic sequence of the virus recovered from a dead Northern Goshawk (SRB-Novi Sad/12) showed a lineage 2 strain (Figure 2) that clusters with the viruses responsible for the most recent human and animal outbreaks reported in neighbouring countries [13-17]. However, SRB-Novi $\mathrm{Sad} / 12$ isolate was unique, as it showed a total of 29 distinctive nucleotides when compared to those circulating in Europe, although this resulted in only one single amino acid change ( $\left.\mathrm{H}_{244 \mathrm{Q}}\right)$ in the nonstructural protein 3 (NS3) region.

Comparison of partial sequences of the $E$ region from five additional WNV sequences recovered from respective birds in this study shows that at least two different groups of lineage 2 strains, which simultaneously circulated during summer of 2012, can be distinguished (Figure 3). Those that exactly match that of SRB-Novi $\mathrm{Sad} / 12$ isolate and those showing four to five synonymous nucleotide variations in comparison to SRB-Novi $\mathrm{Sad} / 12$. Except for the presence of an additional nucleotide change $\left(\mathrm{C}_{171} \mathrm{~T}\right)$ in the sequence recovered from a goshawk, the sequences in this second cluster present only a single nucleotide variation with a strain recently isolated in Greece in 2010 [14].

These results suggest that WNV has reached the country in, at least, two different events. Our results also suggest that the virus not only has become endemic in Serbia and surrounding countries, but that it is also evolving while circulating in the area. According to these findings, it seems plausible to think that since its original detection in Hungary, WNV lineage 2 has expanded southwards and reached Serbia recently. However, as until very recently WNV has been an almost neglected disease in the region, it cannot be ruled out that there had been prior sporadic human and animal cases that 
have gone unnoticed. Nevertheless, re-introduction of the virus in the future by migratory birds should be monitored.

In August 2012, the first reported WNV outbreak in humans occurred in Serbia [23], with 58 West Nile fever cases. Even though, no WNV genomic sequences are available from these human cases, our data suggest that they were most likely caused by lineage 2 strains similar to the ones reported here.

In summary, the present study provides the first evidence for the presence of WNV infection among wild birds in Serbia, and reports the isolation and characterisation of the first WNV strains in the country. WNV recovered from Serbian birds represent two clusters of lineage 2 strains closely related to other lineage 2 strains currently circulating in neighbouring countries. It is reasonable to think that similar lineage 2 viruses have been responsible for the 2012 first human clinical outbreak reported in Serbia. The data reported here, and the fact that WNV is already endemic in other neighbouring countries, suggests that further WNV infections are likely to occur in Serbia in the future. Therefore, in our opinion, additional epidemiological studies and a state-of-the art surveillance system for the detection of incursions of WNV into Serbia deems mandatory.

\section{Acknowledgements}

This work was supported by grant TR 31084 from the Serbian Ministry of Education Science and Technological Development (MPNTR); the by bilateral project 'Assessment of zoonotic viral activity in Serbia' (AIB2010SE-00316) funded by MPNTR and the Spanish Ministerio de Ciencia e Innovación (MICINN), by grant RTA2011-00036 from the Instituto Nacional de Investigación y Tecnología Agraria y Alimentaria (INIA) and by the Network of Animal Disease Infectiology and ResearchEuropean Union (NADIR-EU-228394). DF is student at the Department for Veterinary Science, Faculty of Agriculture, University of Novi Sad, Serbia. The research groups thank the Rehabilitation Centre in ZOO Palic for providing the succumbed birds carcasses samples.
References

1. Komar N. West Nile virus: epidemiology and ecology in North America. Adv Vir Res. 2003; 61:185-234. http://dx.doi. org/10.1016/So065-3527(03)61005-5

2. Linke S, Niedrig M, Kaiser A, Ellerbrok H, Müller K, Müller T, et al. Serologic evidence of West Nile virus infections in wild birds captured in Germany. Am J Trop Med Hyg. 2007;77(2):358-64. PMid:17690413

3. Hubálek Z, Halouzka J, Juřicová Z, Šikutová S, Rudolf I, Honza $M$, et al. Serologic survey of birds for West Nile flavivirus in southern Moravia (Czech Republic). Vector Borne Zoonotic Dis. 2008;8(5):659-66. http://dx.doi.org/10.1089/vbz.2007.0283. PMid:18454599

4. Jourdain E, Zeller HG, Sabatier P, Murri S, Kayser Y, Greenland T, et al. Prevalence of West Nile Virus Neutralizing Antibodies in Wild Birds from the Camargue Area, Southern France. J Wild Dis. 2008;44(3):766-71. http://dx.doi.org/10.7589/0090-355844.3.766. PMid:18689669.

5. Lopéz G, Jiménez-Clavero MA, Tejedor CG, Soriguer R, Figuerola J. Prevalence of West Nile virus neutralizing antibodies in Spain is related to the behavior of migratory birds. Vector Borne Zoonotic Dis. 2008;8(5):615-21. http:// dx.doi.org/10.1089/vbz.2007.0200. PMid:18399777.

6. Seidowski D, Ziegler U, von Rönn JA, Müller K, Hüppop $\mathrm{K}$, Müller T, et al. West Nile virus monitoring of migratory and resident birds in Germany. Vector Borne Zoonotic Dis. 2010;10(7):639-47. http://dx.doi.org/10.1089/vbz.2009.0236. PMid:20854016.

7. Jourdain E, Olsen B, Lundkvist A, Hubálek Z, Šikutová S, Waldenström J, et al. Surveillance for West Nile Virus in Wild Birds from Northern Europe. Vector Borne Zoonotic Dis. 2011;11(1):77-9. http://dx.doi.org/10.1089/vbz.2009.0028. PMid:20518642.

8. Ziegler U, Seidowski D, Angenvoort J, Eiden M, Müller K, Nowotny N, et al. Monitoring of West Nile Virus Infections in Germany. Zoonoses Public Health. 2012;59 Suppl 2:95-101. http://dx.doi.org/10.1111/zph.12015. PMid:22958253.

9. Figuerola J, Soriguer R, Rojo G, Gómez-Tejedor C, JiménezClavero MA. Seroconversion in wild birds and local circulation of West Nile virus, Spain. Emerg Infect Dis. 2007; 13(12):1915-7. http://dx.doi.org/10.3201/eid1312.070343. PMid:18258046. PMCid:PMC2876749.

10. Shelite TR, Rogers CM, Litzner BR, Johnson RR, Schneegurt MA. West Nile virus antibodies in permanent resident and overwintering migrant birds in south-central Kansas. Vector Borne Zoonotic Dis. 2008;8(3):321-9. http:// dx.doi.org/10.1089/vbz.2007.0176. PMid:18471059. PMCid:PMC 2978050.

11. Martín-Acebes MA, Saiz JC. West Nile virus: a re-emerging pathogen revisited. World J Virol. 2012;1(2):51-70. http://dx.doi. org/10.5501/wjv.v1.i2.51

12. Bakonyi T, Ivanics E, Erdélyi K, Ursu K, Ferenczi E, Weissenböck $\mathrm{H}$, et al. Lineage 1 and 2 strains of encephalitic West Nile virus, central Europe. Emerg Infect Dis. 2006; 12(4):618-23. http://dx.doi.org/10.3201/eid1204.051379. PMid:16704810. PMCid:PMC3294705.

13. Savini G, Capelli G, Monaco F, Polci A, Russo F, Di Gennaro $A$, et al. Evidence of West Nile virus lineage 2 circulation in Northern Italy. Vet Microbiol. 2012;158(3-4):267-73. http:// dx.doi.org/10.1016/j.vetmic.2012.02.018. PMid:22406344.

14. Papa A. West Nile virus infections in Greece: an update. Expert Rev Anti Infect Ther. 2012;10(7):743-50. http://dx.doi. org/10.1586/eri.12.59. PMid:22943398.

15. Erdélyi K, Ursu K, Ferenczi E, Szeredi L, Rátz F, Skáre J, et al. Clinical and pathologic features of linage 2 West Nile virus infections in birds of prey in Hungary. Vector Borne Zoonotic Dis. 2007;7(2):181-8. http://dx.doi.org/10.1089/ vbz.2006.0586. PMid:17627436.

16. Wodak E, Richter S, Bagó Z, Revilla-Fernández S, Weissenböck $\mathrm{H}$, Nowotny $\mathrm{N}$, et al. Detection and molecular analysis of West Nile virus infections in birds of prey in the eastern part of Austria in 2008 and 2009. Vet Microbiol. 2011;149(34):358-66. http://dx.doi.org/10.1016/j.vetmic.2010.12.012. PMid:21276665.

17. Bagnarelli P, Marinelli K, Trotta D, Monachetti A, Tavio M, Del Gobbo R, et al. Human case of autochthonous West Nile virus lineage 2 infection in Italy, September 2011. Euro Surveill. 2011;16(43). pii=20002. Available from: http://www. eurosurveillance.org/ViewArticle.aspx?Articleld=20002. PMid:22085600.

18. Vesenjak-Hirjan J, Punda-Polić V, Dobec M. Geographical distribution of arboviruses in Yugoslavia. Journal of Hygiene, Epidemiology, Microbiology and Immunology (Prague). 1991;35:129-40. 
19. Hubálek Z, Halouzka J. West Nile Fever - a re-emerging Mosquito-borne viral disease in Europe. Emerg Inf Dis. 1999:5(5):643-50. http://dx.doi.org/10.3201/eido505.990506. PMCid:PMC 2627720.

20. Bordjoski M, Gligic A, Boskovic R. Arbovirusne infekcije u SR Srbiji. [Arbovirus infections in Serbia]. Vojnosanit Pregl. 1972;29(4):173-5. Serbian.

21. Petric D, Hrnjakovic-Cvjetkovic I, Radovanov J, Cvjetkovic D, Jerant-Patic V, Milosevic V, et al. West Nile virus surveillance in humans and mosquitoes and detection of cell fusing agent virus in Vojvodina province (Serbia). HealthMed. 2012;6(2):462-8.

22. Lupulovic D, Martín-Acebes MA, Lazic S, Alonso-Padilla J, Blázquez AB, Escribano-Romero $E$, et al. First serological evidence of West Nile virus activity in horses in Serbia. Vector Borne Zoonotic Dis. 2011;11(9):1303-5. http://dx.doi. org/10.1089/vbz.2010.0249. PMid:21438694.

23. Popović N, Milošević B, Urošević A, Poluga J, Lavadinović L, Nedelijković J, et al. Outbreak of West Nile virus infection among humans in Serbia, August to October 2012. Euro Surveill. 2013;18(43):pii=20613. Available from: http://www. eurosurveillance.org/ViewArticle.aspx?Articleld =20613

24. Córdoba L, Escribano-Romero E, Garmendia A, Saiz JC. Pregnancy increases the risk of mortality in West Nile virusinfected mice. J Gen Virol. 2007;88(Pt 2):476-80. http://dx.doi. org/10.1099/vir.0.82439-0. PMid:17251565.

25. Blázquez AB, Saiz JC. West Nile virus (WNV) transmission routes in the murine model: intrauterine, by breastfeeding and after cannibal ingestion. Virus Res. 2010; 151(2):240-3. http:// dx.doi.org/10.1016/j.virusres.2010.04.009. PMid:20438776.

26. Martin-Acebes MA, Saiz JC. A West Nile virus mutant with increased resistance to acid-induced inactivation. J Gen Virol. 2011;92(Pt 4): 831-40. http://dx.doi.org/10.1099/vir.0.027185o. PMid:21228127.

27. Alonso-Padilla J, Jiménez de Oya N, Blázquez AB, Loza-Rubio E, Escribano JM, Saiz JC, et al. Evaluation of an enzymelinked immunosorbent assay for detection of West Nile virus infection based on a recombinant envelope protein produced in Trichoplusia ni larvae. J Virol Methods. 2010;166(12):37-41. http://dx.doi.org/10.1016/j.jviromet.2010.02.013. PMid:20170681.

28. Alonso-Padilla J, Jiménez de Oya N, Blázquez AB, EscribanoRomero E, Escribano JM, Saiz JC. Recombinant West Nile virus envelope protein $\mathrm{E}$ and domain III expressed in insect larvae protects mice against West Nile disease. Vaccine 2011;29(9):1830-5. http://dx.doi.org/10.1016/j. vaccine.2010.12.081. PMid:21211580.

29. Vazquez A, Jimenez-Clavero M, Franco L, Donoso-Mantke O, Sambri V, Niedrig M, et al. Usutu virus: potential risk of human disease in Europe. Euro Surveill. 2011; 16(31):pii=19935. Available from: http://www.eurosurveillance.org/ViewArticle. aspx?Articleld $=19935$

30. Dereeper A, Guignon V, Blanc G, Audic S, Buffet S, Chevenet F, et al.. Phylogeny.fr: robust phylogenetic analysis for the non-specialist. Nucl Acids Res. 2008;36(Web Server issue): W465-469. 